\title{
Matrix Acidizing Characteristics in Shale Formations
}

James Sheng ${ }^{1 *}$, Samiha Morsy ${ }^{1}$, Ahmed Gomaa ${ }^{2}$ and Soliman MY'

${ }^{1}$ Department of Petroleum Engineering, Texas Tech University, Box 43111, Lubbock, TX 79409-3111 USA

${ }^{2}$ Baker Hughes Company, 11211 FM 2920 Rd, Tomball, TX 77375 USA

\begin{abstract}
Matrix acidizing is typically used to remove drilling and completion damage to reservoir conductivity around the wellbore and dissolve calcite in natural fractures. Despite being a common procedure, few studies have investigated the effect of matrix acidizing on the physical properties and oil recovery factors in shales. This paper describes the effect of $\mathrm{HCl}$ acid on porosity, spontaneous imbibition, mechanical properties, and crack distribution in samples from the Eagle Ford, Mancos, Barnett and Marcellus shale formations. Some of the samples were completely immersed in different $\mathrm{HCl}$ solutions $(1-3 \mathrm{wt} \%)$ at $93^{\circ} \mathrm{C}$. We measured the porosity in both the acid-treated and non-treated samples. The treated and non-treated samples were then exposed to spontaneous water imbibition experiments to measure the improvement in oil recovery in both parallel and perpendicular to bedding planes. The mechanical properties of the acid-treated and non-treated samples were also measured in both parallel and perpendicular to bedding planes using the same acid concentrations. The samples were 2.54 and $3.81 \mathrm{~cm}$ in diameter and 2.54 to $5.08 \mathrm{~cm}$ in length. The measured porosities were $1-3 \%$ for the non-treated samples and $1.3-10.5 \%$ for the treated samples. We observed that the oil recovery factors of the spontaneous imbibition for the samples treated with acid were $47 \%$ from Eagle Ford, $53 \%$ from Mancos, $28 \%$ from Barnett, and $38 \%$ from Marcellus. The recovery factors from the non-treated samples were $12 \%$ from Eagle Ford, $4 \%$ from Mancos, $13 \%$ from Barnett, and $3 \%$ from Marcellus. Furthermore, we observed that spontaneous imbibition parallel to bedding planes is higher than imbibition in perpendicular to bedding planes direction, especially for Marcellus samples where the recovery factors varied from $4 \%$ for the samples drilled parallel to bedding planes to $38 \%$ for the samples drilled in perpendicular to bedding planes. Eagle Ford and Mancos samples showed a reduction in confining compressive strength ranging from 50$60 \%$ when exposed to $3 \mathrm{wt} \% \mathrm{HCl}$ solutions with more reduction in the samples drilled parallel to bedding planes.
\end{abstract}

Keywords: Shale formations; Oil recovery

\section{Introduction}

Acidizing treatments are commonly used to remove near wellbore damage and create artificial flow channels in carbonate formations, while limited treatments were done on shale rocks [1]. Shale formations may have highly variable mineralogies, which makes it difficult to predict the consequences of matrix acidizing. It is also important to consider damage mechanisms when designing a matrix treatment, as dissolving calcite, quartz, or clay minerals may affect the reservoirs differently [2]. Shales usually have natural microfractures [3] and acid may enhance microfracture conductivity. A limited number of studies have quantified the effect of $\mathrm{HCl}$ on physical properties of shale formations [4] and almost no information is known about its effect on shale oil recovery.

There are two stimulation techniques employed as alternatives to propped fracturing; matrix acidizing and acid fracturing. Matrix
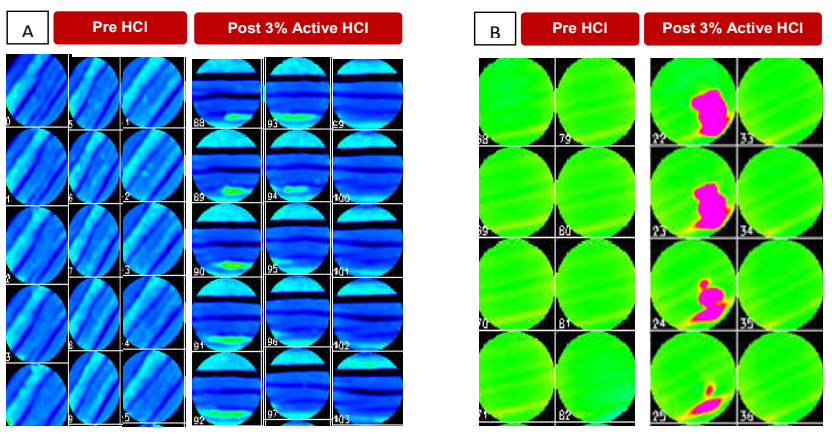

Figure 1: False-colored scanning computer tomography images for Barnett (A) and Marcellus (B) shale. acidizing is performed at low pressures to avoid fracturing the reservoir rock when acid is pumped into the well and permeability is increased by acid dissolution of sediment and mud solids. Permeability is enhanced by enlarging the natural pores of the reservoir and stimulating flow of hydrocarbons in immediately proximity to the wellbore.

Acid fracturing involves pumping highly pressurized acid into the well, physically fracturing the reservoir rock and dissolving sediments to improve permeability. This process forms channels through which the hydrocarbons may flow (Figures 1-10) [5]. The most common acid employed to stimulate production is hydrochloric $(\mathrm{HCl})$, which is useful in removing carbonates from reservoirs. Hydrochloric acid may be combined with hydrofluoric acid (HF), which dissolves silicate phases from the reservoir rocks [2]. In order to protect the integrity of the already completed well, inhibitor additives are introduced to the well to prohibit the acid from breaking down the steel casing in the well. Also, a sequestering agent can be added to block the formation of gels or precipitate of iron, which can clog the reservoir pores during an acid job. After an acid job is performed, the used acid and sediments removed from the reservoir are washed out of the well in a process called backflush.

*Corresponding author: James Sheng, Texas Tech University, USA, Tel: 806834-8477; E-mail: james.sheng@ttu.edu

Received October 06, 2014; Accepted October 16, 2014; Published October 25, 2014

Citation: Sheng J, Morsy S, Gomaa A, Soliman MY (2014) Matrix Acidizing Characteristics in Shale Formations. J Pet Environ Biotechnol 5: 194. doi:10.4172/2157-7463.1000194

Copyright: ( 2014 Sheng J, et al. This is an open-access article distributed under the terms of the Creative Commons Attribution License, which permits unrestricted use, distribution, and reproduction in any medium, provided the original author and source are credited. 
Citation: Sheng J, Morsy S, Gomaa A, Soliman MY (2014) Matrix Acidizing Characteristics in Shale Formations. J Pet Environ Biotechnol 5: 194. doi:10.4172/2157-7463.1000194

Page 2 of 10
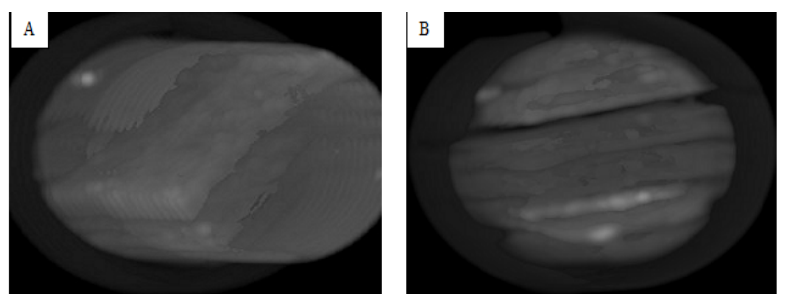

Figure 2: Barnett sample 3D image before and after $3 \% \mathrm{HCl} ; \mathrm{A}$ (before $\mathrm{HCl}$ ) and $\mathrm{B}$ (after $\mathrm{HCl})$
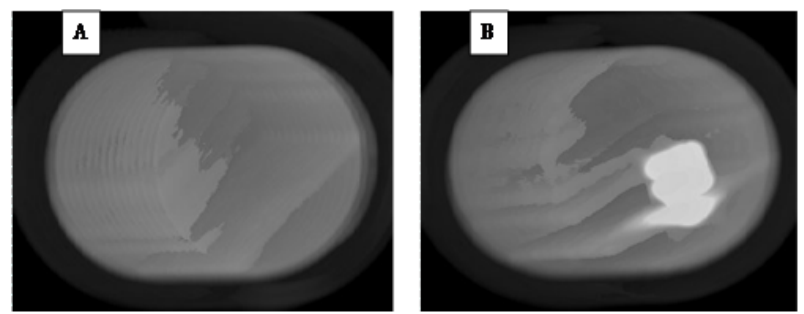

Figure 3: Marcellus sample 3D image before and after $3 \% \mathrm{HCl}$; $\mathrm{A}$ (before $\mathrm{HCl})$ and $\mathrm{B}($ after $\mathrm{HCl})$.
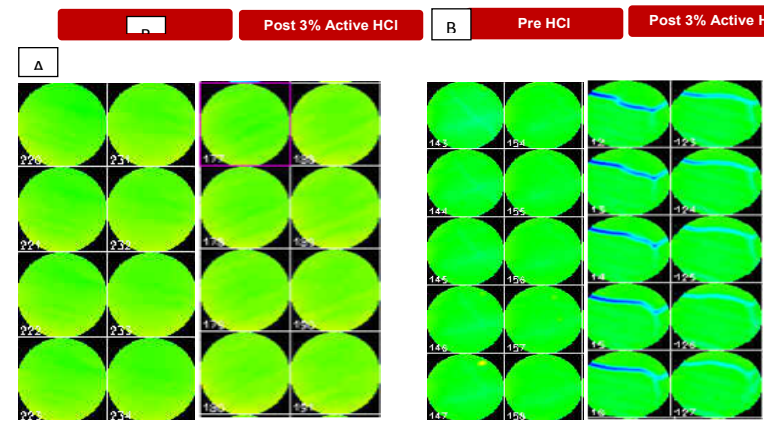

Figure 4: False-colored scanning computer tomography images for Eagle Ford $(A)$ and Mancos $(B)$ shale samples pre \& post $\mathrm{HCl}$.
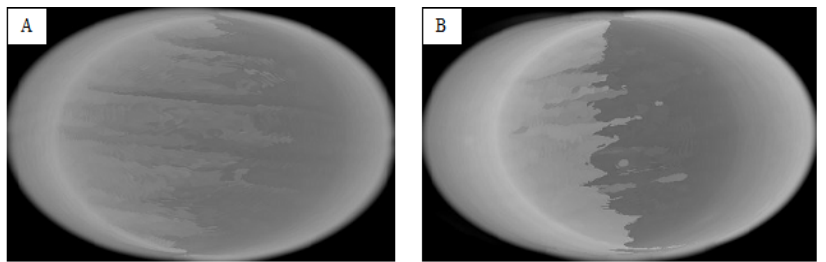

Figure 5: Eagle Ford sample 3D image before and after 3\% $\mathrm{HCl} ; \mathrm{A}$ (before $\mathrm{HCl})$ and $\mathrm{B}($ after $\mathrm{HCl})$.
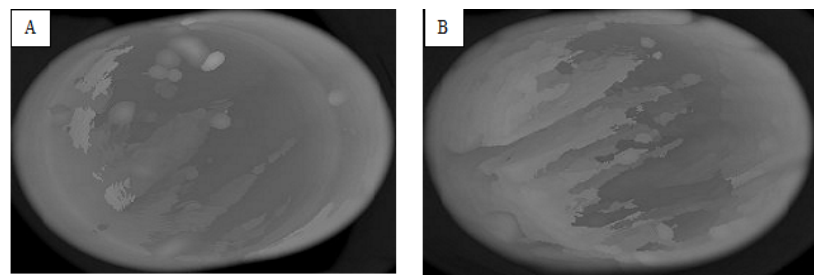

Figure 6: Mancos sample 3D image before and after $3 \% \mathrm{HCl}$; $\mathrm{A}$ (before $\mathrm{HCl}$ ) and $\mathrm{B}($ after $\mathrm{HCl})$.
A new application of combining the benefits of acidizing and propped hydraulic fracturing in unconventional shale formation showed a great improvement in gas production of Woodford shale formation, as acid is not only injected as a pre-flush treatment, but also is used in different sub-stages of the hydraulic-fracturing process away from wellbore [6]. In hydraulic fracturing treatments of Woodford shale, acid slugs are used away from wellbore to free some of the adsorbed gas by dissolving calcite and dolomite crystals [6]. This study used XRD analysis on a shale similar to Woodford. The Caney shale samples treated with weak $\mathrm{HCl}$ solution $(3 \%)$, showed a great improvement in pore connectivity after 3 hours of immersion in $\mathrm{HCl}$, although no deductible amount of calcite or dolomite were detected by XRD analysis after acid treatment.

Developing appropriate strategies for shale acidizing may significantly increase oil and gas production [7], despite lowering Young's modulus. A successful example is the Monterey shale in California, which has a low Young's modulus (1-2 E6 psi), but, due to their silica-rich nature the shale remains highly productive [1].

This study is to investigate the effects of low concentration $\mathrm{HCl}$ on porosity, fractures, mechanical property (triaxial compressive stress) and imbibition oil recovery factors.

\section{Shale Rocks Used in this Study}

Reservoir core samples from Eagle Ford, and outcrop samples from Mancos, Barnett, and Marcellus shale formations were used in this study. The formations have differing mineral assemblages. Eagle Ford shale is calcite-clay rich but quartz-poor $[8,9]$. Macos is quartz-illite rich but carbonate poor [10].

The Eagle Ford Shale contains a much higher and highly variable volume of carbonate up to $70 \%$. With progression towards the northwest, the clay content increases, as the formation is exploitable at shallower depths. The Mancos is predominately steel-gray sandy shale but includes stringers of earthy coal, impure limestones, and many thin beds of fine-grained yellow and brown sandstone that are chiefly composed of sub angular and angular quartz grains cemented by lime [10]. Barnett is a very brittle gas bearing siltstone [8]. The Barnett Shale consists of marine clays, primarily illite and chlorite, detrital silt-sized quartz, silicified and carbonate bioclasts and fossils, interstitial organic carbon, and phosphate. Most Barnett Shales are siliceous mudstones, rich in quartz, and may be considered argillaceous siltstones. Some of the Barnett lithofacies are insensitive to acid, due to low volumes of carbonate, but moderately sensitive to freshwater. Other lithofacies have higher abundances of carbonate, and are therefore more reactive to matrix acidizing [11].

The Marcellus formation is dominated by interspersed limestone beds [12]. Bedding is well developed and, as one would expect of shale, it often splits parallel to bedding planes. Pyrite is also relatively rich in

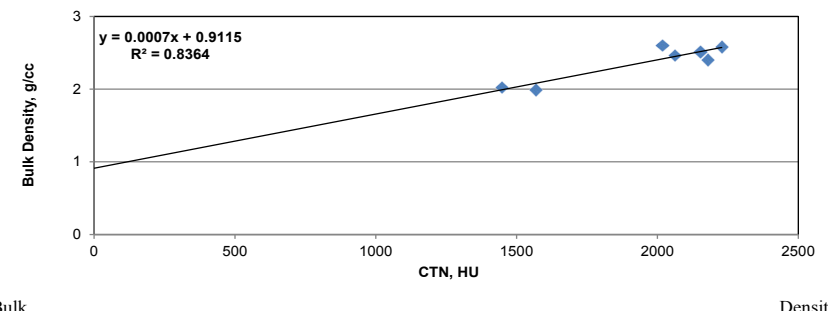

$=0.0007 * \mathrm{CTN}+0.9115$

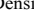

Figure 7: Bulk density-CTN correlation 
Citation: Sheng J, Morsy S, Gomaa A, Soliman MY (2014) Matrix Acidizing Characteristics in Shale Formations. J Pet Environ Biotechnol 5: 194. doi:10.4172/2157-7463.1000194
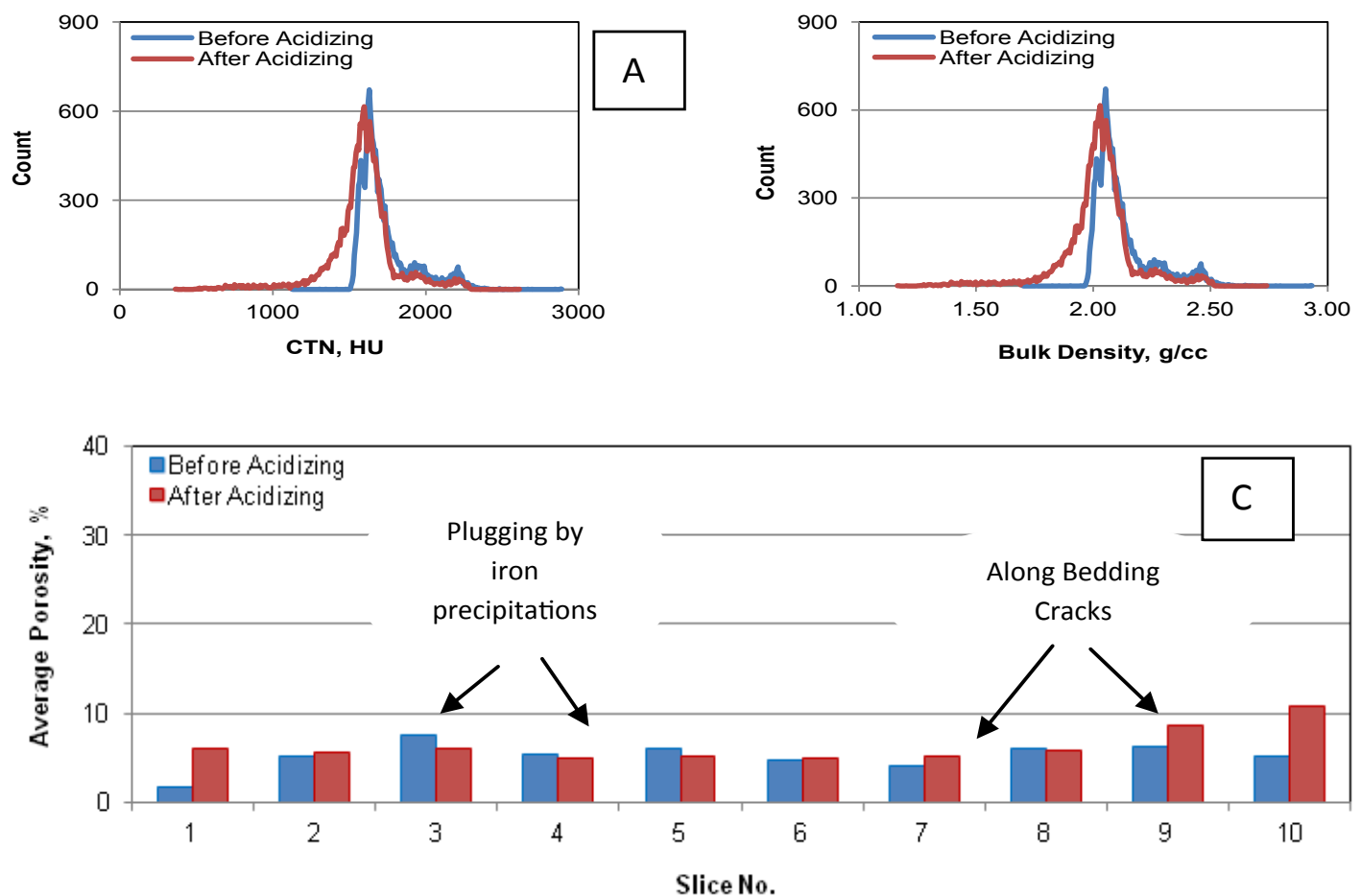

Figure 8: (a) Barnett sample's CTN histogram, (b) Bulk density histogram and (c) Average porosity per slice before and after 1 wt\% $\mathrm{HCl}$.
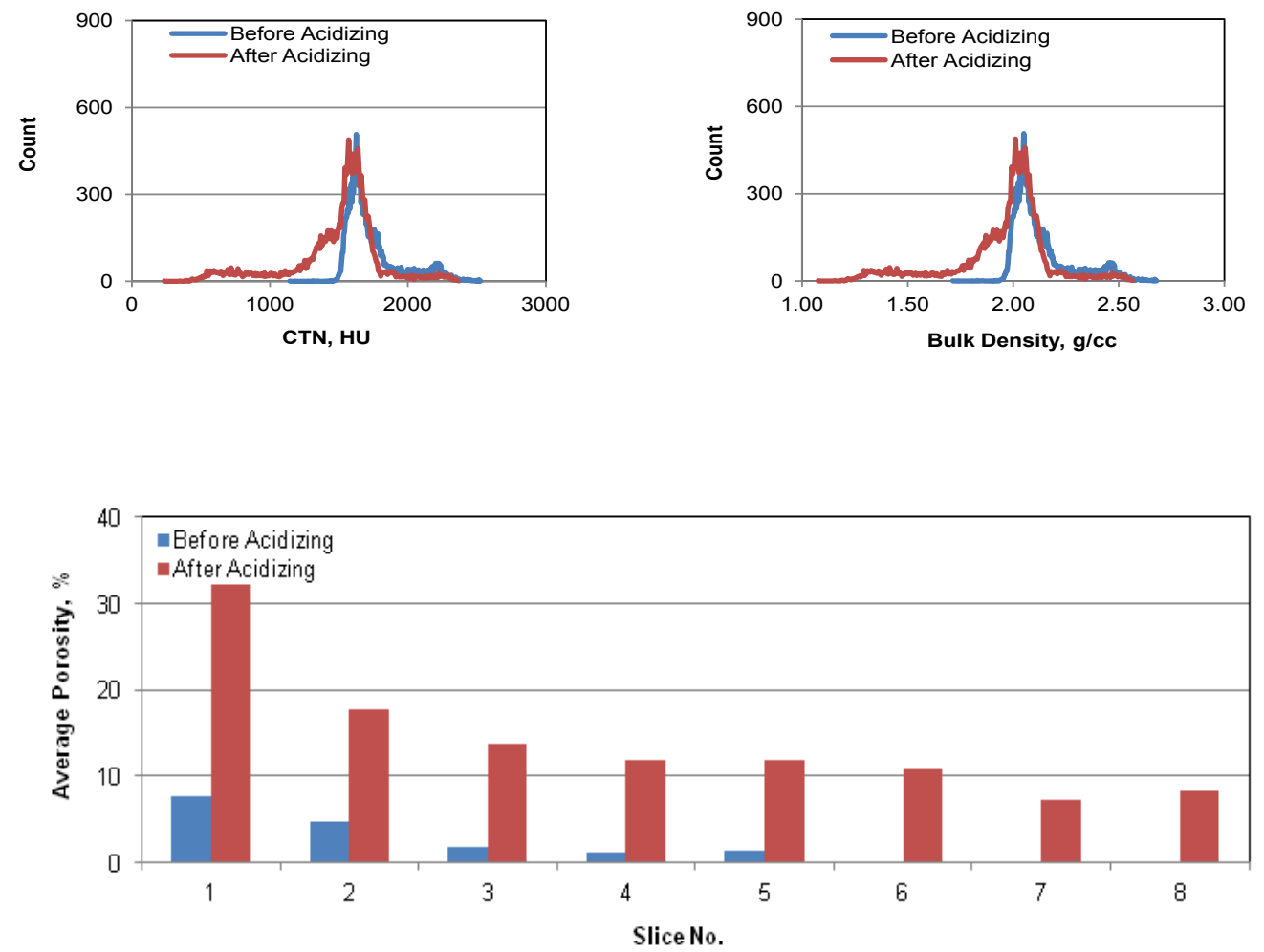

Figure 9: (a) Barnett sample's CTN histogram, (b) Bulk density histogram and (c) Average porosity per slice before and after 2 wt\% $\mathrm{HCl}$. 
Citation: Sheng J, Morsy S, Gomaa A, Soliman MY (2014) Matrix Acidizing Characteristics in Shale Formations. J Pet Environ Biotechnol 5: 194. doi:10.4172/2157-7463.1000194
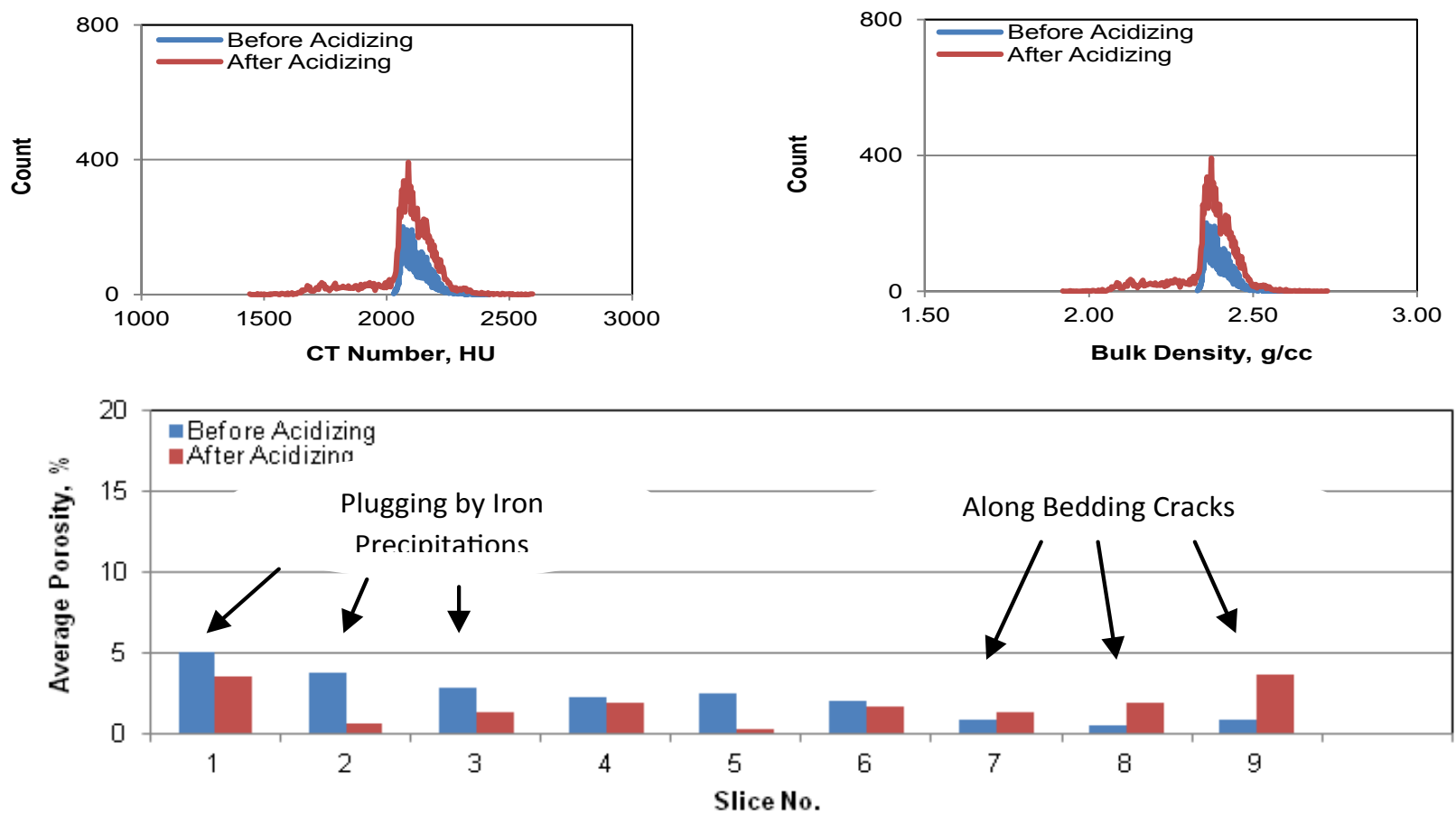

Figure 10: (a) Marcellus sample's CTN histogram, (b) Bulk density histogram and (c) Average porosity per slice before and after $1 \mathrm{wt} \% \mathrm{HCl}$.

\begin{tabular}{|c|c|c|c|c|}
\hline \multirow{2}{*}{ Mineral } & Barnett $^{\mathrm{a}}$ & Marcellus $^{a}$ & Mancos $^{b}$ & Eagle Ford ${ }^{c}$ \\
\hline & $(w t \%)$ & $(w t \%)$ & $(w t \%)$ & $(w t \%)$ \\
\hline Quartz & $35-50$ & $10-60$ & $36-43.4$ & 9 \\
\hline Clays, primarily illite & $10-50$ & $10-35$ & $30.2-42.4$ & 26 \\
\hline Calcite, dolomite, siderite & $0-30$ & $3-50$ & $9.5-18$ & 53 \\
\hline Feldspars & 7 & $0-4$ & $5.2-8.8$ & 2 \\
\hline Pyrite & 5 & $5-13$ & $1-2.6$ & 4 \\
\hline Phosphate, gypsum, Apatite & trace & Trace & trace & 1 \\
\hline Mica & 0 & $5-30$ & trace & Trace \\
\hline TOC & $0.36-9.7$ & $0.3-11$ & $0.4-3.1$ & $3-7$ \\
\hline
\end{tabular}

Table 1: Typical mineral composition for studied shales.

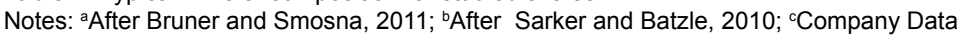

this shale. The mineral composition of the studied shales is presented in Table 1.

\section{Experimental Procedures}

\section{Porosity and spontaneous imbibition procedures}

To eliminate clay swelling during the matrix acidizing experiments $[13,14]$, acid solutions were prepared by mixing $\mathrm{HCl}$ with $\mathrm{NaCl}$ solutions. A $30 \mathrm{wt} \% \mathrm{NaCl}$ solution was used for experiments with Mancos shale samples and a $2 \mathrm{wt} \% \mathrm{NaCl}$ solution was used for experiments with the Eagle Ford, Barnett, and Marcellus shale samples. The sodium chloride salinities were chosen based on recommended slick-water compositions that minimize clay swelling in each of the respective shale types [8].

Representative samples of each shale were selected and dried under normal atmospheric conditions at $93^{\circ} \mathrm{C}$ for a minimum of 8 hours. Each sample was then weighed, oriented and placed in a Neurologica CereTom NL3000 Computed Tomography Scanner for porosity measurements. The same samples were then immersed in 1,2 or $3 \mathrm{wt} \%$
$\mathrm{HCl}$ saline solutions for contact for 3 hours. Samples were removed from the solutions, dried at $104^{\circ} \mathrm{C}$ for two hours. All samples (acid-treated and untreated) were placed in a desiccator and subjected to vacuum saturation pumping for 48 hours. Each sample was saturated in Soltrol $130^{\mathrm{mw}}$ mineral oil at atmospheric conditions $\left(25^{\circ} \mathrm{C}, 100 \mathrm{kPa}\right)$ for two weeks. Samples were removed from the oil and excess oil was allowed to drain at ambient conditions. Oil saturated samples were weighed $\left(\mathrm{W}_{\text {sat }}\right)$ and then placed in the CT scanner for re-analysis. Samples were mounted in the scanner in the same orientation and alignment as they were for scanning prior to acidizing. Porosity was calculated for airsaturated and oil-saturated samples using (Equation 1) as following:

$$
\phi=\frac{C T_{o m}-C T_{a m}}{C T_{0}-C T_{a}}
$$

where $\mathrm{CTN}$ is a normalized value of the calculated $\mathrm{X}$-ray absorption coefficient of a pixel (picture element) in a computed tomogram expressed in Hounsfield units, the CT number of air $\left(C T_{a}\right)$ is -1000 , and the measured value for Soltrol $130^{\mathrm{rx}}\left(C T_{o}\right)$ was -215 . The CT numbers for the air-saturated $\left(C T_{a m}\right)$ and oil-saturated $\left(C T_{o m}\right)$ samples 
Citation: Sheng J, Morsy S, Gomaa A, Soliman MY (2014) Matrix Acidizing Characteristics in Shale Formations. J Pet Environ Biotechnol 5: 194. doi:10.4172/2157-7463.1000194

Page 5 of 10

\begin{tabular}{|c|c|c|c|c|c|c|}
\hline & Shale & Length & Diameter & Volume & Dry weight & bulk density \\
\hline & & $(\mathrm{cm})$ & $(\mathrm{cm})$ & $\left(\mathrm{cm}^{3}\right)$ & (g) & (g) \\
\hline Intact & Eagle Ford & 4.6 & 3.4 & 41.81 & 131.1 & 3.14 \\
\hline After $3 \% \mathrm{HCl}$ & Eagle Ford & 2.7 & 3.7 & 29.47 & 68.2 & 2.32 \\
\hline Intact & Marcellus & 2.2 & 2.5 & 10.84 & 25.9 & 2.40 \\
\hline After $3 \% \mathrm{HCl}$ & Marcellus & 2.3 & 2.46 & 10.89 & 28.3 & 2.60 \\
\hline Intact & Barnett & 2.7 & 2.46 & 12.95 & 26.2 & 2.02 \\
\hline After $3 \% \mathrm{HCl}$ & Barnett & 2.4 & 2.51 & 12.10 & 24.1 & 1.99 \\
\hline Intact & Mancos & 3.9 & 2.59 & 20.48 & 51.4 & 2.51 \\
\hline After $3 \% \mathrm{HCl}$ & Mancos & 3.9 & 2.59 & 20.34 & 50.1 & 2.46 \\
\hline
\end{tabular}

Table 2: Shale samples properties.

were measured for all shale samples. Image resolution is $0.12 \mathrm{~mm}$ by $0.12 \mathrm{~mm}$ by $1.2 \mathrm{~mm}$.

Oil saturated samples were placed in Amott cells containing the same saline solution used in each matrix acidizing experiment for one week at room temperature and the oil recovery was recorded per day.

\section{Mechanical properties measurements}

To test the effect of low $\mathrm{HCl}$ acid concentrations on shale's mechanical properties, experiments to measure the triaxial strength of representative shale samples before and after matrix acidizing in parallel and perpendicular to bedding orientations were designed. Mineral assemblage quantification indicated that the Eagle Ford shale samples had the highest calcite content. The Eagle Ford also displayed the least crack and fracture content or development during matrix acidizing experiments, and these samples were selected for mechanical testing because they were predicted to be the most susceptible to bulk changes in mechanical properties as a function of exposure of $\mathrm{HCl}$, in the absence of changes caused by crack and fracture density and occurrence. In addition, Mancos samples showed non oriented cracks after acidizing that might affect their mechanical properties and that is why we want to quantify the impact of $\mathrm{HCl}$ on different samples.

All samples were obtained from outcrop shales. The first sample was tested intact and without saline solution or acid treatment. The remaining samples were completely immersed in acid concentrations of $3 \mathrm{wt} \% \mathrm{HCl}$ prepared with $5 \mathrm{wt} \% \mathrm{NaCl}$ solution at $93^{\circ} \mathrm{C}$ and ambient pressure for 180 minutes. All samples were prepared according to specifications of American Society for Testing and Materials ASTM D-2938.

The Eagle Ford and Mancos outcrop samples measuring in $2.54 \mathrm{~cm}$ diameter and 5.5-6.7 cm in length. The samples were prepared in $3 \mathrm{wt} \%$ $\mathrm{HCl}$ and $5 \mathrm{wt} \% \mathrm{NaCl}$ in case of Eagle Ford samples and $30 \mathrm{wt} \% \mathrm{NaCl}$ in case of Mancos samples. The samples were tested under confining pressure of 1000 psi.

\section{Data Analysis and Discussion}

\section{Cracks distribution after matrix acidizing}

Air Saturated (dry) CT scanning images were taken for the studied samples (Table 2) pre \& post $\mathrm{HCl}$ treatment. In addition, 3D constructed images have been developed to show the acid treatment effect on the different studied shale samples. False-colored Scanning Computer Tomography images and scanning computed tomography 3D images of the four studied shales show strongly contrasting responses to acid treatment. Barnett and Marcellus shale samples developed cracks parallel to bedding planes (Figures 1-3) in response to the presence of acidic solution; the size and number of cracks tends to increase with exposure to higher acid solutions, with a greater increase in crack density observed in Barnett samples. The CT-scanning images of postacid treated samples of Barnett and Marcellus shales also show the presence of high density material, not observed in untreated samples (white-colored in Figures 2B and 3B). Based on the higher abundances of pyrite in the Marcellus and Chlorite clay minerals in the Barnett rocks $[15,16]$, the white-colored material was interpreted to be iron oxide-hydroxide precipitation resulted from chlorite dissolution (in the case of Barnett) in acidic solutions and pyrite oxidation (in the case of Marcellus). The precipitation of iron negatively affected the calculated average porosity per slice in some areas in Barnett and Marcellus shale samples (next section). The precipitations plugged some pores in these samples, but did not affect the overall recovery factors and average porosity due to the development of bedding cracks. The effect of iron precipitation is mainly controlled by chlorite and pyrite distribution in the shale samples.

In the Eagle Ford samples, the majority of samples, regardless of acid strength, show rarely visual cracks developing, which is interpreted to represent that increases in porosity are due to calcite dissolution only (Figures $4 \mathrm{~A}$ and $5 \mathrm{~B}$ ). The presented results are in a good agreement with the studies done by [14] who reported that the Eagle Ford shale conductivity is controlled by microfractures, and samples rarely have visible natural fractures.

In the Mancos samples, CT-scanning and 3D images show occasional visible crack development (Figures $4 \mathrm{~B}$ and 6B). The cracks vary in length and are randomly oriented, although their abundance increases towards the surface of the sample. These results are also consistent with the findings of Ridgley [15], who demonstrated that one of the main factors that control production from Mancos shale is fractures.

\section{Effect of matrix acidizing on shale porosity}

In order to identify the effect of $\mathrm{HCl}$ on the bulk density and porosity values of the shale rocks under this study, a bulk density and CT number (CTN) correlation (Equation 2 and Figure 7) was developed with a good accuracy based on the known bulk density of some samples that has been scanned before doing CT scanning for shale rocks.

CTN and bulk density histograms for Barnett, Eagle Ford, and Mancos samples show negative correlations with the used acid concentration (Figures 8-14). As $\mathrm{HCl}$ concentration increased, the measured CTN and calculated bulk density decreased. While the measured CTN and calculated bulk density of Marcellus samples increased with the increase in the used $\mathrm{HCl}$ concentrations, which is owing to the existence of a heavier material developed after acidizing (iron precipitation as discussed in section 4.1 ). The range of bulk density before acidizing was $1.69-2.78 \mathrm{~g} / \mathrm{cc}$ against $1.00-2.34 \mathrm{~g} / \mathrm{cc}$ after acidizing for Barnett, $2.31-2.54 \mathrm{~g} / \mathrm{cc}$ against 1.81-2.72 $\mathrm{g} / \mathrm{cc}$ after acidizing for Marcellus, $2.55-2.95 \mathrm{~g} / \mathrm{cc}$ against 2.53-2.77 g/cc after acidizing for Eagle 
Citation: Sheng J, Morsy S, Gomaa A, Soliman MY (2014) Matrix Acidizing Characteristics in Shale Formations. J Pet Environ Biotechnol 5: 194. doi:10.4172/2157-7463.1000194
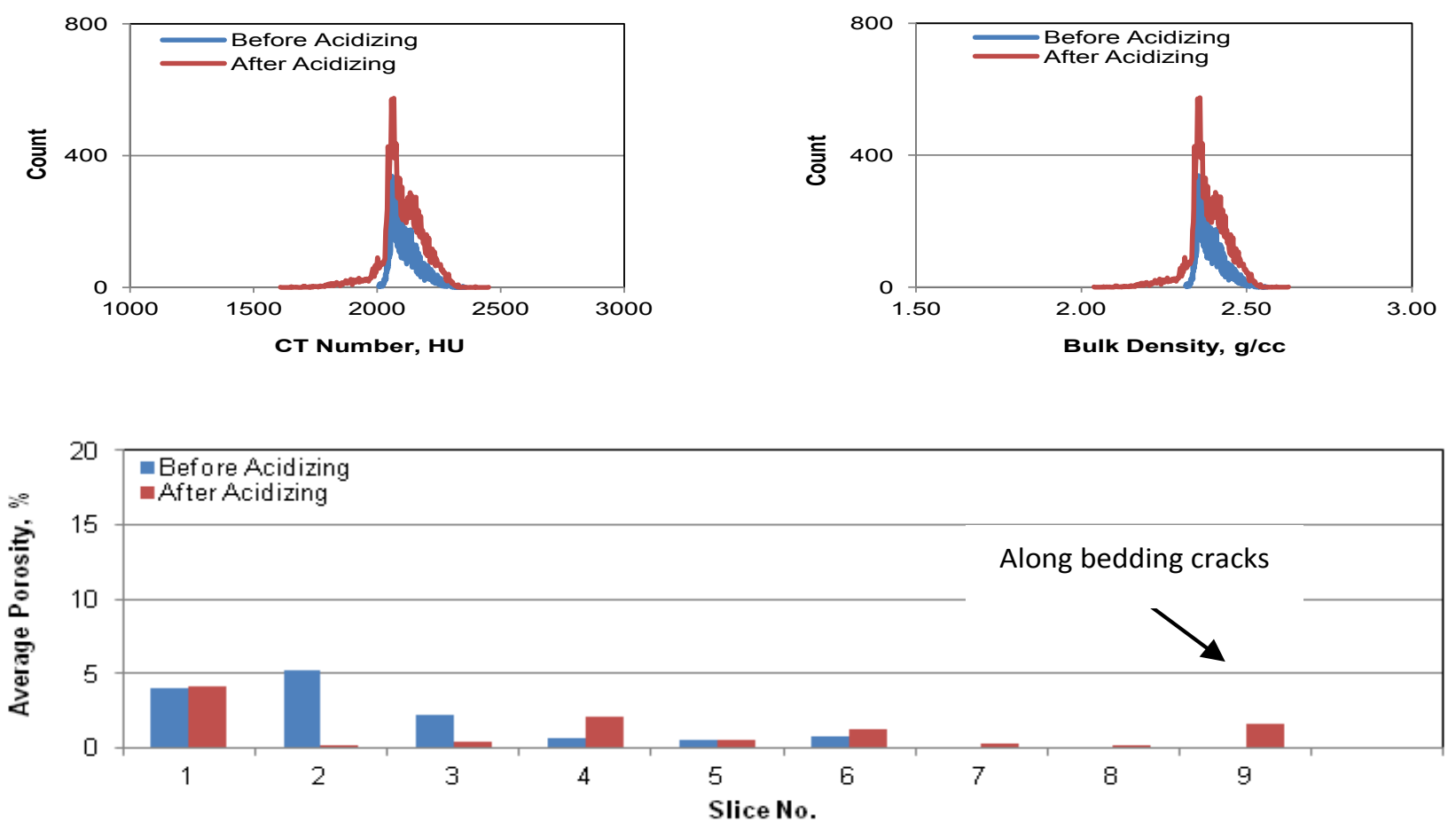

Figure 11: (a) Marcellus sample's CTN histogram, (b) Bulk density histogram and (c) Average porosity per slice before and after 2 wt\% HCl.
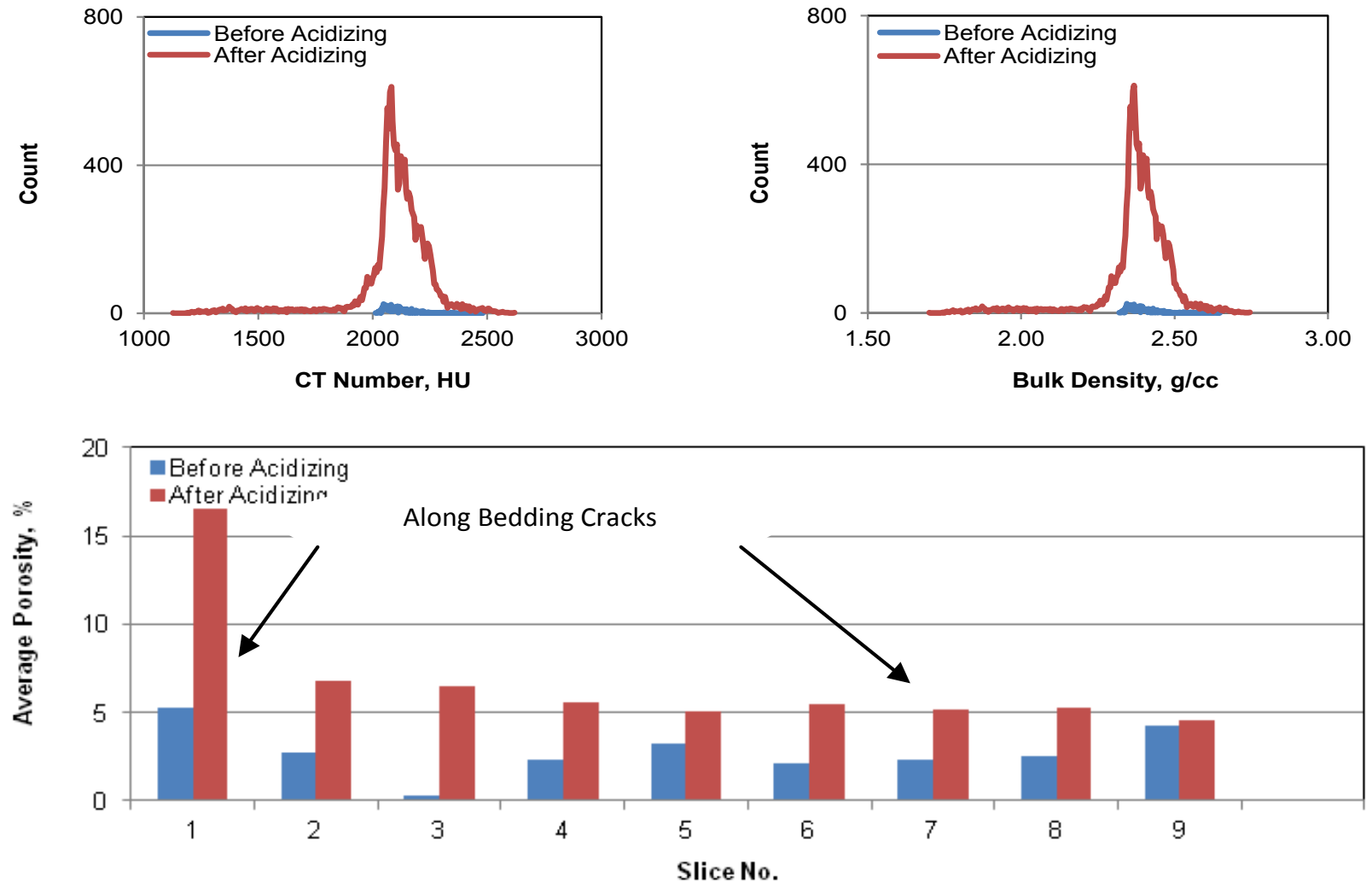

Figure 12: (a) Marcellus sample's CTN histogram, (b) Bulk density histogram and (c) Average porosity per slice before and after 3 wt\% $\mathrm{HCl}$. 
Citation: Sheng J, Morsy S, Gomaa A, Soliman MY (2014) Matrix Acidizing Characteristics in Shale Formations. J Pet Environ Biotechnol 5: 194. doi:10.4172/2157-7463.1000194
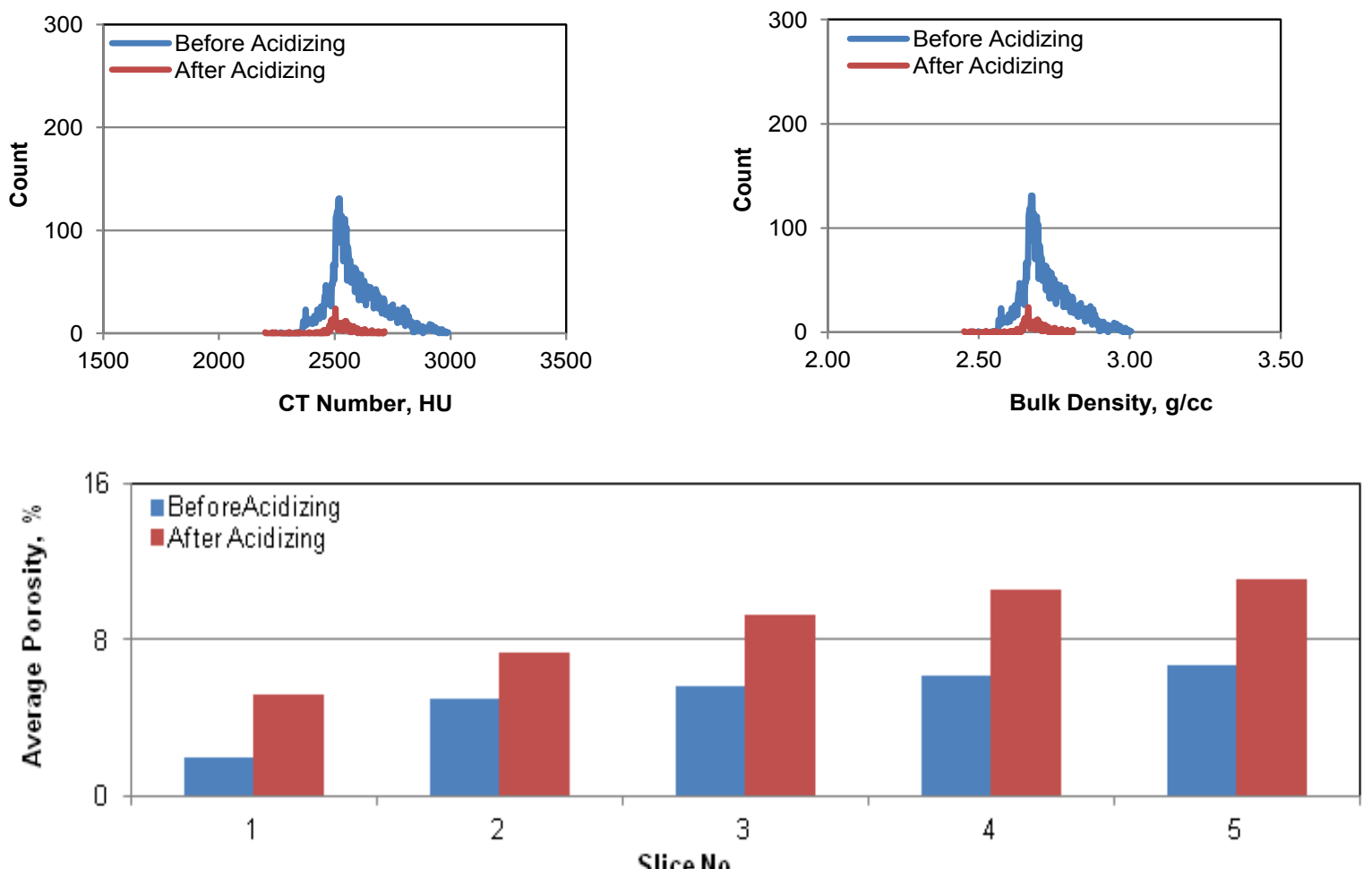

Figure 13: (a) Eagle Ford sample's CTN histogram, (b) Bulk density histogram and (c) Average porosity per slice before and after 3 wt $\%$ HCl.
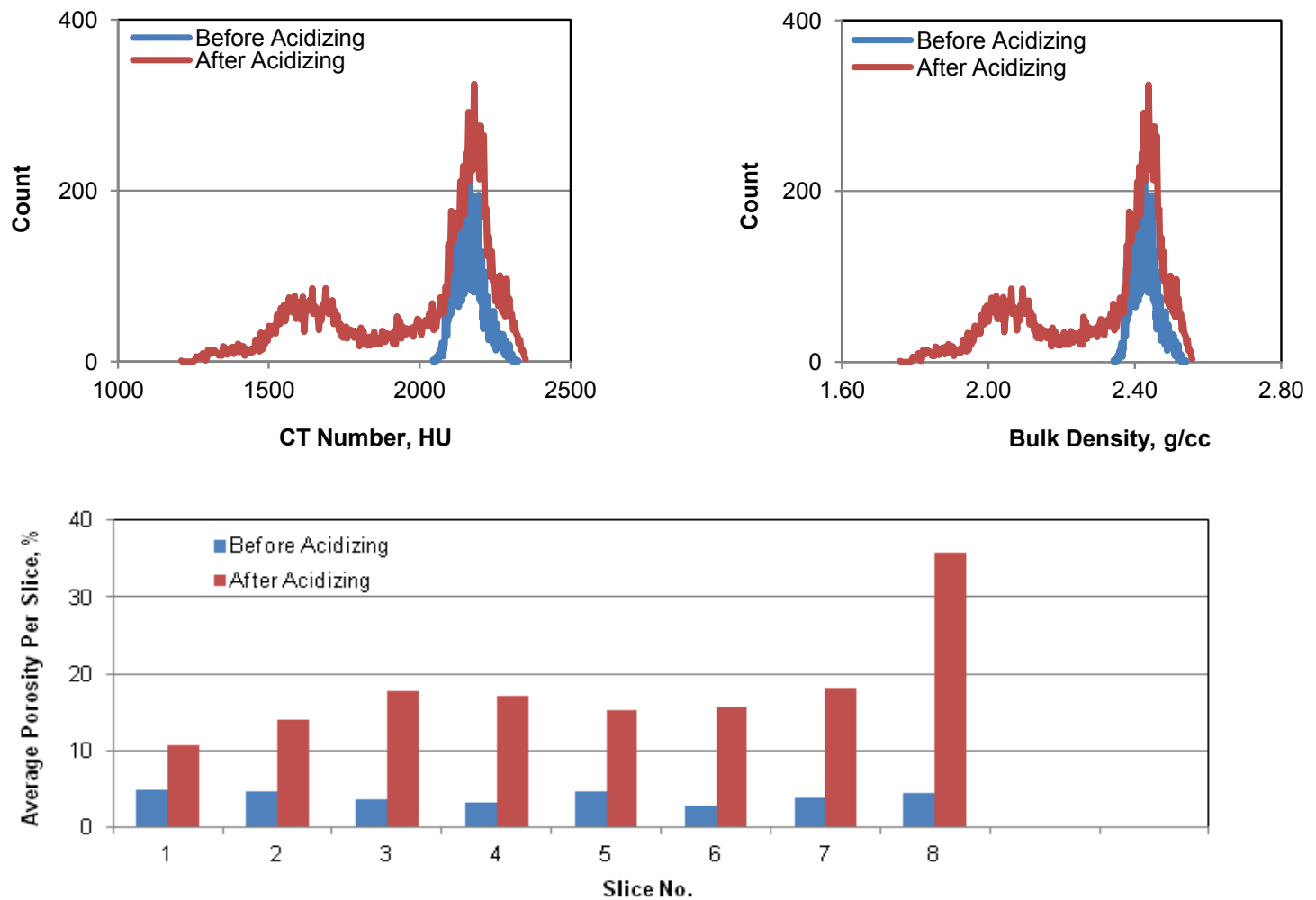

Figure 14: (a) Mancos sample's CTN histogram, (b) Bulk density histogram and (c) Average porosity per slice before and after 3 wt\% $\mathrm{HCl}$. 


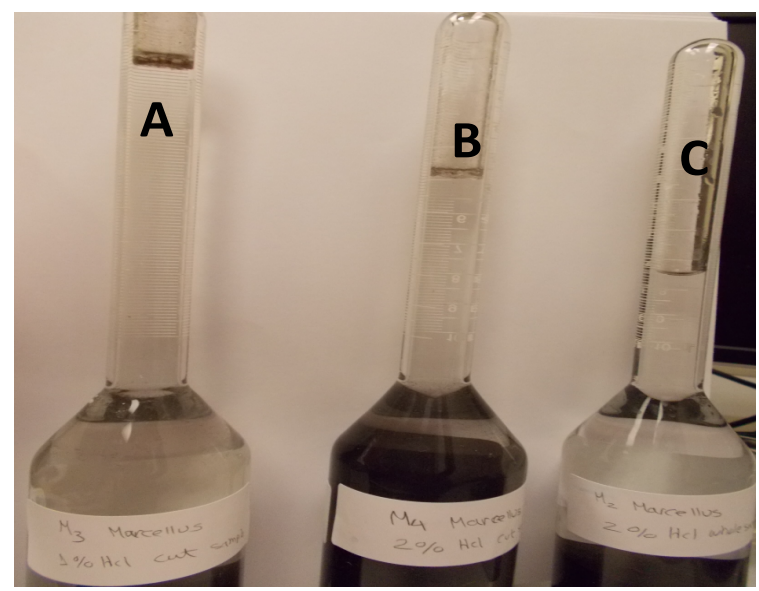

Figure 15: Marcellus Shale samples in spontaneous imbibition cells after treated in different $\mathrm{HCl}$ solutions: A) Marcellus sample cut parallel to bedding after $1 \mathrm{wt} . \% \mathrm{HCl}$ treatment $\quad$ B) Marcellus sample cut parallel to bedding after $2 \mathrm{wt} . \% \mathrm{HCl}$ treatment $\mathrm{C}$ ) Marcellus sample cut perpendicular to bedding after $2 \mathrm{wt} . \% \mathrm{HCl}$ treatment.

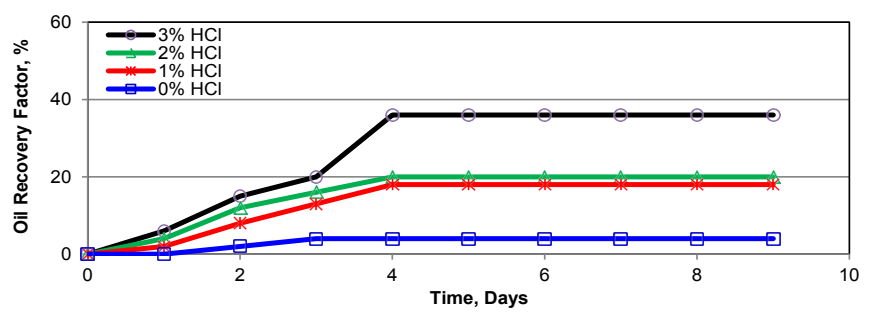

Figure 16: Spontaneous imbibition R.F of Mancos shale (cut perpendicular to bedding).

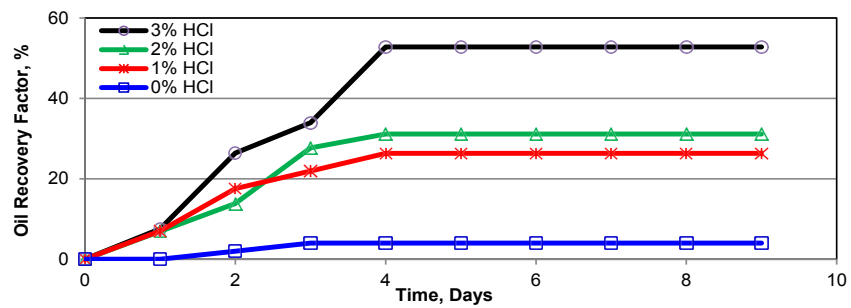

Figure 17: Spontaneous imbibition R.F of Mancos shale (cut parallel to bedding).

Ford, 2.27-2.69 g/cc against $1.8-2.58 \mathrm{~g} / \mathrm{cc}$ after acidizing for Mancos samples.

The average porosity per slice for each sample is calculated pre \& post acid treatment using the measured CTN for the samples saturated with air (dry) and saturated with Soltrol $130^{\mathrm{TM}}$. Average slice porosities for the pre-acid treated samples were 1.7-7.7\% (Barnett), 0.33-5.3\% (Marcellus), 0.23-6.74\% (Eagle Ford), and 0.87-4.74\% (Mancos) (Figures 8C-14C). All samples overall average porosities have been increased after acidizing, which is sometimes related to calcite dissolution (e.g. Eagle Ford) and in other rocks is related to cracks development due to clay dissolution (e.g. Mancos, Barnett, and Marcellus). Post-acid average slice porosities using 1-3 wt\% $\mathrm{HCl}$ were 4.0-32.3\% for (Barnett), 0.2-35.8\% (Marcellus), 1.7-11\% (Eagle Ford), and $1.1-35.78 \%$ (Mancos).
Barnett samples showed an overall increase in the average sample post-porosity in all acidic solutions, but at $1.0 \mathrm{wt} \% \mathrm{HCl}$ the average porosity per slice deceased in some slices inside the sample due to iron precipitation with pronounced increase at the sample surfaces due to parallel to bedding cracks and micro-fracture opening (Figure $8 \mathrm{C})$. However, in the $2.0 \mathrm{wt} \%$ and $3.0 \mathrm{wt} \% \mathrm{HCl}$ acidic solutions, the calculated average post-porosity per slice of the Barnett samples increased significantly in most of the slices inside the samples (Figures 9C) due to excessive parallel to bedding cracks development and microfracture opening.

In the Marcellus samples, the calculated average post-porosity per slice decreases in the $1.0 \mathrm{wt} \%$ and $2 \mathrm{wt} \% \mathrm{HCl}$ experiments due to iron precipitations with clear enhancement at the sample surface due to parallel to bedding cracks (Figures $10 \mathrm{C}$ and $11 \mathrm{C}$ ). However, in the higher acidity solution $(3 \mathrm{wt} \% \mathrm{HCl})$ experiment the post-porosity significantly increases parallel to the whole slices of the sample (Figure 12C) due parallel to bedding cracks that were resulted from more dissolution.

In the Eagle Ford samples (Figure 13), the main mechanisms are porosity enhancement by opening of the natural fractures and secondary porosity development by calcite dissolution. No reduction was observed in the Eagle Ford shale samples' porosities using $\mathrm{HCl}$ up to $3 \%$ that might be related to the type of clay in this shale and its distribution as observed with Barnett and Marcellus shale samples.

Mancos samples showed post-porosity increase (Figure 14) that is well correlated with the loss in bulk density and CTN, with a significant increase in porosity observed in the $3.0 \mathrm{wt} \% \mathrm{HCl}$ experiment. Mancos post-porosity improved to over $30 \%$ porosity due to non-oriented cracks development that was resulted from cementing material (lime) and clay dissolution (Figure 14C).

\section{Effect of fracture orientation on spontaneous imbibition in shale rocks}

Samples were cut parallel and perpendicular to bedding planes to investigate the effect of fracture orientation on rock recoverability. The samples cut parallel to bedding showed a significant improvement in spontaneous imbibition performance for all of the studied shale rocks compared with those that cut perpendicular to bedding and especially for Marcellus that did not respond to any treatment when cut perpendicular to bedding (Figure 15).

The oil recovery factors were $37 \%$ from Eagle Ford samples cut perpendicular to bedding compared with $47 \%$ from those cut parallel to bedding, $36 \%$ from Mancos samples cut perpendicular to bedding compared with $52.8 \%$ from those cut parallel to bedding, $24 \%$ from Barnett perpendicular to bedding against $28 \%$ from parallel to bedding cut Barnett samples, 4 from perpendicular to bedding against $38 \%$ from parallel to bedding cut Marcellus samples (Figures 16-23).

Recovery factors showed no systematic correlation with changes in porosity, carbonate dissolution, and strength of the acid used in most of the experiments (Figures 16-23). The greatest increase in recovery factor was observed in the Mancos shale sample that was exposed to the highest acid-strength solution; recovery factors as high as 53\% were measured against $4 \%$ from the non-treated samples (Figure 16). In the Mancos samples, the increase in recovery factor mirrors the increase in the cracks development during acid treatment and spontaneous imbibition. However, the increase in recovery of Eagle Ford corresponded to carbonates dissolution as no visual cracks were observed. 
Citation: Sheng J, Morsy S, Gomaa A, Soliman MY (2014) Matrix Acidizing Characteristics in Shale Formations. J Pet Environ Biotechnol 5: 194. doi:10.4172/2157-7463.1000194

Page 9 of 10

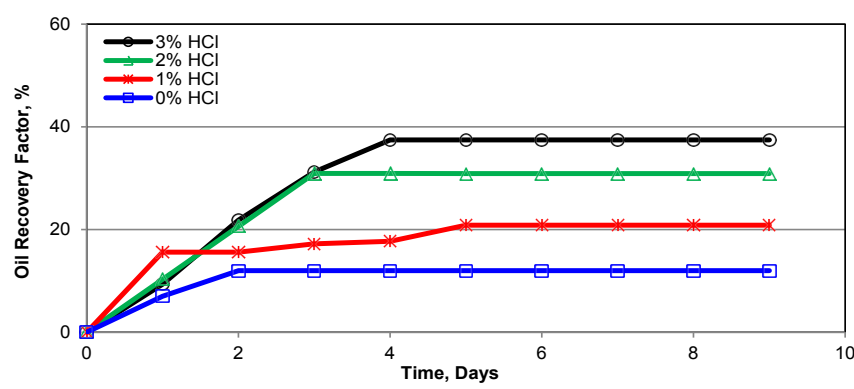

Figure 18: Spontaneous imbibition R.F of Eagle Ford shale (cut perpendicular to bedding).

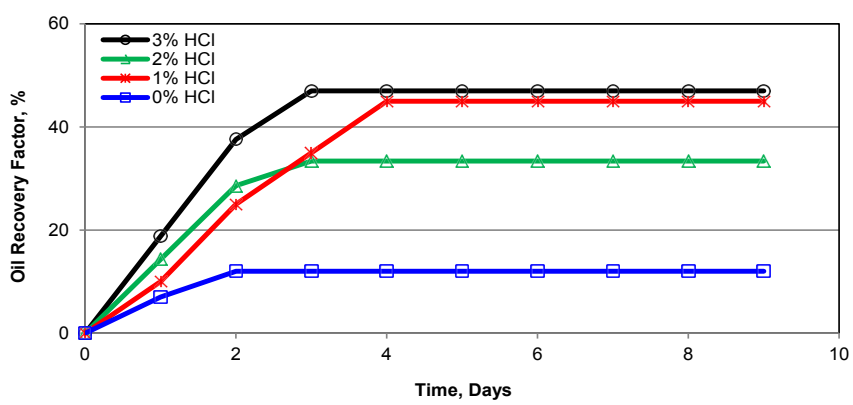

Figure 19: Spontaneous imbibition R.F of Eagle Ford shale (cut parallel to bedding).

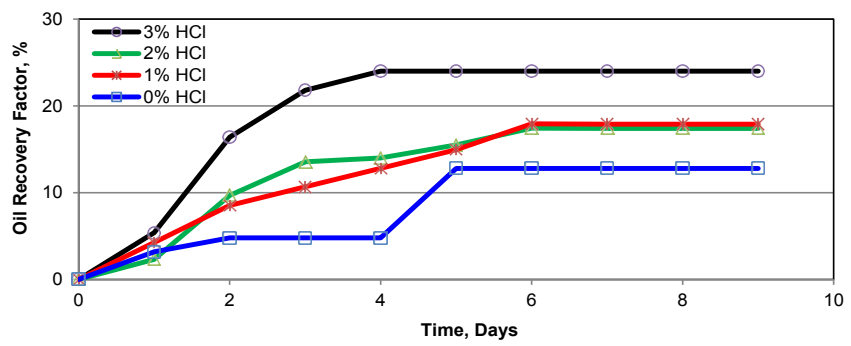

Figure 20: Spontaneous imbibition R.F of Barnett shale (cut perpendicular to bedding).

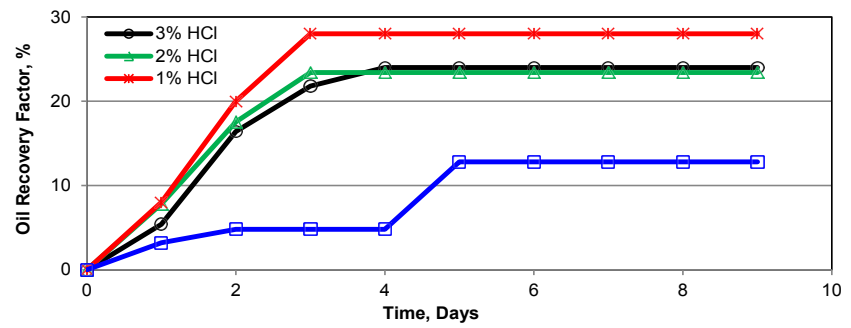

Figure 21: Spontaneous imbibition R.F of Barnett shale (cut parallel to bedding).

The recovery factors for the Barnett and Marcellus samples that cut perpendicular to bedding planes increased with increasing acid concentration, which somewhat correlates with porosity changes in all Barnett and Marcellus samples (Figures 20 and 23). On the other hand, the recovery factors from the samples cut parallel to bedding planes shows a reverse trend as recovery factors decreased as acid strength increases which might be related to the allocation of pyrite mineral that precipitate during experiment.

\section{Effect of $\mathrm{HCl}$ on eagle ford and mancos shales' mechanical properties}

In this study, samples were cut parallel and perpendicular to bedding to investigate the impact of $\mathrm{HCl}$ on mechanical properties in both directions. The measured mechanical properties showed a good correlation with the acidity of the used solution for both Eagle Ford and Mancos samples in both directions (parallel and perpendicular to bedding). The samples cut perpendicular to bedding showed more resistance (more than 30\%) to break down compared with the samples cut parallel to bedding. The loss in the triaxial confined compressive strength using $3 \mathrm{wt} \% \mathrm{HCl}$ was $60 \%$ for Mancos (Table 3), $49 \%$ for Eagle Ford when cut perpendicular to bedding and $61 \%$ for Eagle Ford sample when cut parallel to bedding (Table 4). These results correlate well with our finding about imbibition in parallel and perpendicular bedding directions, where more imbibition was observed when samples cut parallel bedding.

\section{Conclusions}

1. Eagle Ford and Mancos shales' mechanical properties and recovery factors can be significantly enhanced by low acid concentrations (less than $3 \mathrm{wt} \% \mathrm{HCl}$ ).

2. Eagle Ford shale's porosity increased more than two folds, and resulted in a three-fold increase in the recovery factors.

3. Porosities and recovery factors for the Eagle Ford shale were enhanced by partial dissolution of calcite.

4. The higher recovery factors of Mancos shale were caused by development of induced fractures after acidizing.

5. Iron oxide-hydroxide precipitation after pyrite oxidation in Barnett and Marcellus shales lowered porosities at $\mathrm{HCl}$ concentrations less than $2 \mathrm{wt} \%$, but did not affect the recovery factors.

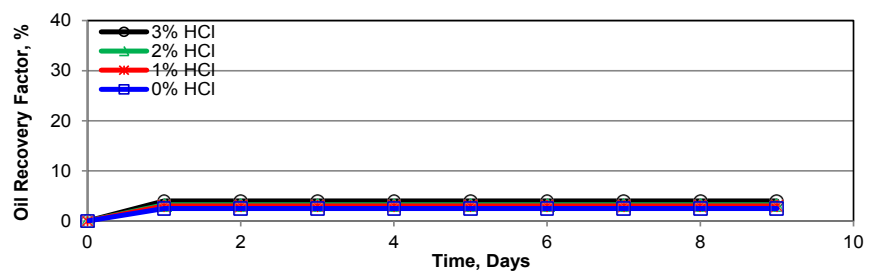

Figure 22: Spontaneous imbibition R.F of Marcellus shale (cut perpendicular to bedding).

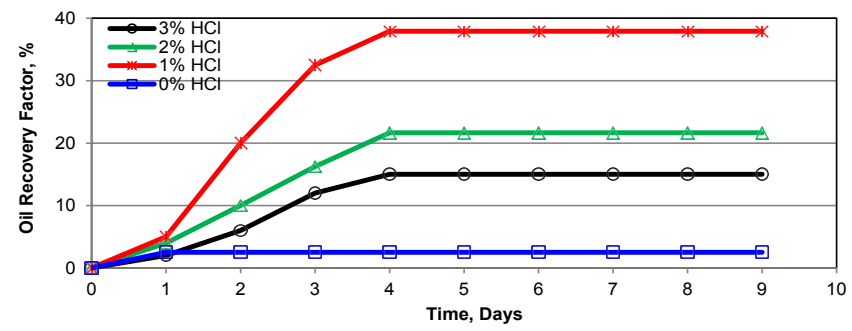

Figure 23: Spontaneous imbibition R.F of Marcellus shale (cut parallel to bedding). 
Citation: Sheng J, Morsy S, Gomaa A, Soliman MY (2014) Matrix Acidizing Characteristics in Shale Formations. J Pet Environ Biotechnol 5: 194. doi:10.4172/2157-7463.1000194

Page 10 of 10

\begin{tabular}{|c|c|c|c|c|c|c|c|c|c|c|c|}
\hline Sample ID & Orientation & $\begin{array}{l}\text { Length } \\
\text { (cm) }\end{array}$ & $\begin{array}{l}\text { Dia. } \\
(\mathrm{cm})\end{array}$ & $\begin{array}{l}\text { Dry Wt. } \\
\text { (g) }\end{array}$ & $\begin{array}{l}\text { Sat. Wt. } \\
\text { (g) }\end{array}$ & $\begin{array}{c}\text { Dry Bulk Density } \\
\text { g/cc }\end{array}$ & $\begin{array}{c}\text { Sat. Density } \\
\text { g/cc }\end{array}$ & $\begin{array}{l}\text { Confining Stress } \\
\text { Psi }\end{array}$ & $\begin{array}{c}\text { YM } \\
\left(1 \times 10^{6} \mathrm{psi}\right)\end{array}$ & PR & $\begin{array}{c}\text { Peak Strength } \\
\text { Psi }\end{array}$ \\
\hline Intact Sample & Parallel & 6.7 & 2.54 & 75.51 & & 2.23 & & 1000 & - & - & 19120 \\
\hline $3 \mathrm{wt} \% \mathrm{HCl}+5 \mathrm{wt} \% \mathrm{NaCl}$ & Parallel & 6.4 & 2.54 & 75.51 & 70.81 & 2.23 & 2.24 & 1000 & 0.45 & 0.09 & 7412 \\
\hline $3 w t \% \mathrm{HCl}+5 w t \% \mathrm{NaCl}$ & Perpendicular & 6.5 & 2.54 & 75.51 & 73.90 & 2.23 & 2.29 & 1000 & 0.67 & - & 9730 \\
\hline
\end{tabular}

Table 3: Mechanical data for Eagle Ford outcrop shale samples.

\begin{tabular}{|c|c|c|c|c|c|c|c|c|c|c|c|}
\hline Sample ID & Orientation & $\begin{array}{l}\text { Length } \\
(\mathrm{cm})\end{array}$ & $\begin{array}{l}\text { Dia. } \\
\text { (cm) }\end{array}$ & $\begin{array}{l}\text { Dry Wt. } \\
\text { (g) }\end{array}$ & $\begin{array}{l}\text { Sat. Wt. } \\
\text { (g) }\end{array}$ & $\begin{array}{c}\text { Dry Bulk Density } \\
\text { g/cc }\end{array}$ & $\begin{array}{c}\text { Sat. Density } \\
\text { g/cc }\end{array}$ & $\begin{array}{c}\text { Confining Stress } \\
\text { Psi }\end{array}$ & $\begin{array}{c}\text { YM } \\
\left(1 \times 10^{6} p s i\right)\end{array}$ & PR & $\begin{array}{l}\text { Peak Strength } \\
\text { Psi }\end{array}$ \\
\hline Intact Sample & Perpendicular & 6.1 & 2.54 & 77.47 & & 2.53 & & 1000 & 1.81 & 0.09 & 16800 \\
\hline $3 w t \% \mathrm{HCl}+30 \mathrm{wt} \% \mathrm{NaCl}$ & Perpendicular & 5.5 & 2.54 & 77.47 & 70.33 & 2.53 & 2.52 & 1000 & 0.76 & 0.26 & 6644 \\
\hline
\end{tabular}

Table 4: Mechanical data for Mancos outcrop shale samples.

6. Imbibition oil recovery factors parallel to bedding planes were higher than that perpendicular to bedding for all of the studied rocks especially for Marcellus rock samples.

7. Low concentrations of $\mathrm{HCl}$ can significantly affect shale mechanical properties with huge loss in confined triaxial compressive strength ranging from $50-60 \%$ using $3 \mathrm{wt} \% \mathrm{HCl}$.

\section{Acknowledgement}

We would like to acknowledge that the Eagle Ford rock samples were provided by Chesapeake.

\section{References}

1. EL Shaari N, Minner WA, LaFollette RF (2011) Is there a "Silver Bullet Technique" to Stimulating California. SPE- 144526-MS presented at SPE Western North American Region Meeting Anchorage, Alaska, USA.

2. Patton BJ, Pitts F, Goeres T, Hertfelder G (2003) Matrix Acidizing Case Studies for the Point Arguello Field, SPE Western Regional/AAPG Pacific Section Joint Meeting, Long Beach, California, USA.

3. Taylor R, Fyten GC, McNeil F (2012) Acidizing-Lessons from the Past and New Opportunities, SPE Canadian Unconventional Resources Conference, Calgary, Alberta, Canada.

4. Fontaine J, Johnson N, Schoen D (2008) Design, Execution, and Evaluation of a "Typical" Marcellus Shale Slickwater Stimulation: A Case History, SPE Eastern Regional/AAPG Eastern Section Joint Meeting, Pittsburgh, Pennsylvania, USA.

5. Bale A, Smith MB, Henry Klein HH (2010) Stimulation of Carbonates Combining Acid Fracturing With Proppant (CAPF): A Revolutionary Approach for Enhancement of Final Fracture Conductivity and Effective Fracture HalfLength, SPE Annual Technical Conference and Exhibition, Florence, Italy.

6. Grieser B, Wheaton B, Magness B, Blauch M, Loghry R (2007) Surface Reactive Fluid's Effect on Shale, Production and Operations Symposium, Oklahoma City, Oklahoma, USA.

7. Runtuwene M, Fasa MH, Rachmawati FD, Wijanarko M, Kadarsyah A, et al (2010) Crosslinked Acid as An Effective Diversion Agent in Matrix Acidizing IADC/SPE Asia Pacific Drilling Technology Conference and Exhibition, Ho Chi Minh City, Vietnam.
8. Borstmayer K, Stegent N, Wagner A (2011) Approach Optimizes Completion Design. The American Oil and Gas Reporter.

9. Fan L, Martin R, Thompson J, Atwood K, Robinson J, Lindsay G (2011) An Integrated Approach for Understanding Oil and Gas Reserves Potential in Eagle Ford Shale Formation, Canadian Unconventional Resources Conference, Alberta, Canada.

10. Torsæter M, Vullum PE, Nes OM (2012) Nanostructure vs. Macroscopic Properties of Mancos Shale, SPE Canadian Unconventional Resources Conference, Calgary, Alberta, Canada.

11. Rickman R, Mullen M, Petre E, Grieser B, Kundert D (2009). Petrophysics Key In Stimulating Shales. The American Oil and Gas Reporter,USA.

12. Bruner KR, Smosna R (2011) A Comparative Study of the Mississippian Barnett Shale, Fort Worth Basin, and Devonian Marcellus Shale, Appalachian Basin, National Energy Technology Laboratory (NETL), U.S. Department of Energy.

13. Morsy S, Sheng J, Ezewu R (2013) Potential of Waterflooding in Shale Formations, SPE Nigeria Annual International Conference and Exhibition, Lagos, Nigeria.

14. Guo Q, Ji L, Rajabov V, Friedheim J, Portella C, Wu R (2012) Shale Gas Drilling Experience and Lessons Learned From Eagle Ford, Americas Unconventional Resources Conference, Pittsburgh, Pennsylvania USA.

15. Ridgley J (2002) Sequence Stratigraphic Analysis and Facies Architecture of the Cretaceous Mancos Shale on and Near the Jicarilla Apache Indian Reservation, New Mexico- their relation to Sites of Oil Accumulation. Combined Final Technical Report on Mancos Shale Phase 1 and Phase 2, NETL, USA

16. Simon DE, Anderson MS (1990) Stability of Clay Minerals in Acid, SPE Formation Damage Control Symposium, Lafayette, Louisiana, USA. 